\title{
Gallus gallus domesticus Linnaeus, 1758: Keep safe your domestic fowl from your domestic foul
}

\section{Siddharth Biswas*}

Central Zone,

National Cave Research and Protection Organization, Raipur, 492001 C.G.

Study Area: Raipur, India

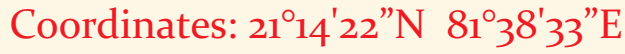

Key words: chicken, domestic fowl, thermocol, styrofoam, polystyrene, Gallus gallus domesticus

\section{Introduction}

Universally, today the ill effects of pesticides/insecticides in agricultural practices have been well realized due to which a certain percentage of health cautious human population has started to prefer the eco-friendly agricultural products inspite of its high cost. On the other side, majority of us consume protein-rich foods, mainly from animal origin, viz., meat from various origins (goat, sheep, birds, pigs, fish and seafood/shellfish), milk and eggs to obtain our nutritional requirements instantly. Food safety and its systematic distribution are now a days an issue of international concern. The negligence in such issues has resulted various serious consequences especially when the food is of animal origin.

It could not be overlooked that day by day various chemical resources are directly or indirectly consumed by our food producing animals which ultimately results in adulteration of our food products. The ingested and even inhaled chemical components are seen to accumulate in animal tissues, or are emanate in milk and even accumulate in eggs, which ultimately causes health problem in consumers i.e., directly on us (Lozano \& Trujillo, 2012).

Solid wastes are broadly categorized into three types:

1) Domestic wastes which lie scattered around us and its proper disposal must be our own responsibility.

2) Industrial wastes, technically known as hazardous wastes for which some major systematic steps are required to get rid of it.

3) Biomedical wastes or the hospital wastes which are indeed also the infectious wastes, usually not disposed anomalously, however proper procedure is always required to remove it.

My article is widely focused on one of the most common domestic waste, polystyrene

*Corresponding Author: sid@caves.res.in 


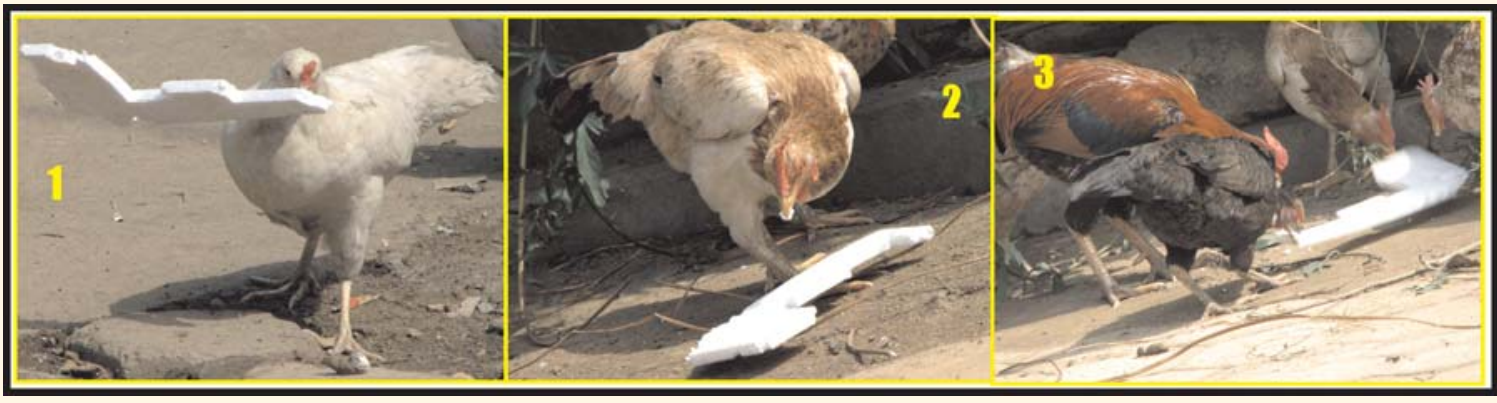

Figures: Hen coming with a piece of polystyren in her beak.

Then after, one by one all the fellow fowls started to nibbel the same.

(trade name Thermocol, Styrofoam etc.)which is widely used as a disposable item (use and throw) and is always found around us. Low weight, rigidity, and formability are some of its technically important inherent properties, due to which polystrene is used in large quantities for industrial/domestic packing purposes.It has also been seen to be used in our eateries, in the form of thermocol plates, bowls and glasses. As per a report, in Pune (a city of india) alone, virtually $1,000 \mathrm{~kg}$ polystyrene waste is being disposed every day either in open spaces, garbage bins, drains or gullies leading to pollution (TOI, 2012).

\section{Polystyrene: Thermocol / Styrofoam:}

Polystyrene is manufactured by the polymerisation of styrene or phenylethene and the chemical properties of phenylethene are identical to polyethene. In nature its degradation takes place very slowly which also makes the soil infertile. On burning it releases carcinogenic dioxins and furans, which in excess quantity can even choke our respiratory tracts, resulting to death. Polystyrene as a marine litter already has created a catastrophe on the marine environment. As per Allsopp et al., (2006) more than 267 different marine species including seabirds, turtles, seals, sea lions, whales and fish are known to be infected due to ingestion of marine litter. Ecologists have already threatened that the consumption of plastic debris is creating a hazard to wildlife which ultimately gets transfer such toxic chemicals to our food chain. From the very beginning the styrene monomer (from which polystyrene is made) is a cancer suspect agent, but due to its presence in very low levels in consumer products the risk factor is ignored (Cohen et al., 2002).

\section{Environmental Contamination:}

As a daily routine, domestic garbage accumulates in the backyard of our Institution, which is frequently disposed by the Municipal department. I have always noticed that the domestic fowls (Gallus gallus domesticus) from neighborhood always visit the garbage in search of its preferable food stuffs. Interestingly, whenever the pieces of polystyrenes are accumulated in such garbage the domestic fowls prefer the same as their edible food. One day surprisingly I noticed an interesting sight, that a fowl with a big piece of polystyrene/thermocol $(1 \mathrm{X} 1 \mathrm{ft}$ approximate with thickness $1 / 2$ ") in its beak was approaching the group of its kin who were busy 
feeding the regular poutry feed at the same time (Figure-1). No sooner than the fowl approached in their vicinity, all the fowls abandoned their eating and joined it in devouring the polystyrene. Within no time, all the fowls had devoured the complete piece (Figure-2\&3).

I was watching the same episode since last few years and didn't notice any casualty so far in the folk relate to the same. Further, while accessing the internet I also found the same report elsewhere uploaded in 'Youtube', (a video-sharing website). Now, the question arises whether consumption of such polysterene by the domestic fowls is polluting our food chain or not? The styrene monomer has already been reported to force its way from polystyrene packaging to our food stuffs which has been considered as the greatest contamination source of our food stuffs. Styrene was reported with the concentrations of $2.580 \mu \mathrm{g} / \mathrm{kg}$ in yoghurt and other milk products packed in polystyrene containers, which increase with the duration of storage (Air quality guidelines for Europe, 200o). Based on limited evidence of carcinogenicity, Styrene is also reasonably anticipated to be a human carcinogen (Cohen et al., 2002; Report on Carcinogens, 2011).

Nevertheless, styrene in little concentration is also known to be naturally present in our various food stuffs, such as strawberries, beef, and spices usually as a byproduct of fermentation and thus its occurrence has been suggested to be out of danger how far the human health is concerned (Cohen et al., 2002).

Conclusively, the accumulation of polystyrene/ styrene in a very small quantity in the body of such domestic fowl may not prove to be a life risk factor for them, instead whether the accumulation of such carcinogenic materials in the food chain is acceptable for the human health or not is yet to be debated.

\section{Acknowledgements}

I wish to acknowledge my father and mother (Dr. Jayant \& Anupama Biswas) who helped me to scientifically documented by personal obserations on domestic fowls.

\section{References:}

Air quality guidelines for Europe (200o): Copenhagen, World Health Organization Regional Office for Europe, , pp. 273 (WHO Regional Publications, European Series, No. 23).

Allsopp M., Walters A., Santillo D. \& Johnston P. (2006): Plastic Debris in the World's Oceans.Greenpeace International publication pp. 44 .

Cohen J.T., Carlson G., Charnley G., Coggon D., Delzell E., Graham J.D., Greim H., Krewski D., Medinsky M., Monson R., Paustenbach D., Petersen B., Rappaport S., Rhomberg L., Ryan P.B. \& Thompson K. (2002): A comprehensive evaluation of the potential health risks associated with occupational and environmental exposure to styrene. LToxicol. Environ. Health B.Crit. Rev., 5(1-2):1-265.

Lozano M.C. \& Trujillo M. (2012): Chemical Residues in Animal Food Products: An Issue of Public Health in Public Health - Methodology. In- Jay Maddock eds., Environmental and Systems Issues . 163-188.

Report on Carcinogens, 12th Edition (2011): National Toxicology Program, Depart. of Health and Human Services.

TOI (2012): PMC to set up thermocol waste processing plant (a report by: Prasad Kulkarni). http://timesof india.indiatimes.com/city/pune/PMC-to-set-up-thermocol-waste-processingplant/articleshow/12155568.cms

Vijayakumar K., Muthuraman M. \& Jayaraj R. (2013): Propagating Trigona iridipennis Colonies (Apidae: Meliponini) ByEduction Method. Scholars Academic Journal of Biosciences, 1(1): 1-3.

Author is a school going student (XII) 